\title{
KEPEMIMPINAN LAKI-LAKI DALAM KELUARGA: Implementasinya pada Masyarakat Jawa
}

\author{
Sri Suhandjati \\ Universitas Islam Negeri Walisongo Semarang \\ e-mail: srieshan.21@gmail.com
}

\begin{abstract}
The interpretation of leadership in the family has an important role to construct Sakinah family. Because of difference interpretation effects to household violence. The difference is trough leadership criteria whether absolutely be every man or just for certain man who is able to fulfill the requirement as written in Q.S. al-Nisā' [4]: 34. This writing has a purpose to discuss absolute leadership pattern and functional leadership and the effect to the family. The description of leadership that discussed in this writing is about Javanese culture that has centralistic leadership and demand absolute obedience. One of the effects of practices absolute leadership is household violence. Violence in a family as the most little unit of society will effect to the existence of form a group and have a nation. Furthermore, exegesis that has the perspective of equality gender by observing local culture must be developed, in order to be easy to be understood and to be carried out.
\end{abstract}

\begin{abstract}
Abstrak: Pemahaman mengenai kepemimpinan laki laki dalam keluarga, berperan penting untuk membangun keluarga sakinah. Namun, terdapat perbedaan dalam menafsirkan kriteria kepemimpinan dalam keluarga. Apakah kepemimpinan bersifat mutlak bagi setiap laki-laki atau hanya untuk laki-laki tertentu yang dapat memenuhi syarat sebagaimana disebutkan dalam QS. al-Nisa' [4]: 34. Tulisan ini bertujuan untuk membahas pemahaman tentang ayat yang terkait dengan kepemimpinan dalam keluarga dan implementasinya dalam kehidupan masyarakat Jawa. Pendekatan Antropologis digunakan untuk mendapatkan deskripsi mengenai tradisi kepemimpinan dalam keluarga di lingkungan masyarakat Jawa. Hasil temuan dari pembahasan ini adalah adanya pemahaman yang sentralistik terhadap ayat kepemimpinan dalam keluarga, sehingga berdampak pada terjadinya Kekerasan Dalam Rumah Tangga (KDRT). Apabila keluarga sebagai unit terkecil dari masyarakat mengalami kekerasan, tentu akan berpengaruh pada kehidupan bermasyarakat dan berbangsa. Oleh karenanya, perlu dikembangkan pemahaman yang berperspektif kesetaraan jender dengan memperhatikan kearifan lokal, agar mudah dipahami dan dilaksanakan.
\end{abstract}

Keywords: family leadership; centralistic; Javanese culture

\section{A. Pendahuluan}

Islam mengajarkan bahwa laki laki adalah pemimpin dalam keluarga, sehingga mereka bertanggungjawab membimbing anggota keluarganya kejalan yang diridhai Allah. Syarat menjadi pemimpin adalah adanya kelebihan laki laki 
atas perempuan dan kemampuan mereka dalam menafkahi istri dan anaknya. Meskipun sebagian besar mufassir sepakat mengenai kepemimpinan laki-laki dalam keluarga, tetapi terdapat perbedaan pendapat terkait syarat seorang laki laki dapat menjadi pemimpin. Sebagian mufasir berpendapat bahwa kepemimpinan secara otomatis melekat pada setiap laki laki, seperti yang dijelaskan dalam QS. al-Nisa' [4]: 34. Namun adapula mufassir yang berpendapat bahwa ada persyaratan yang harus dipenuhi untuk menjadi pemimpin dalam keluarga, sehingga ada kemungkinan kepemimpinan tidak selamanya berada di tangan laki-laki.

Penerapan tafsir tentang mutlaknya kepemimpinan laki laki dalam keluarga telah menjadi tradisi dalam masyarakat Jawa. Laki laki adalah pemimpin bagi perempuan, dan menempati kedudukan tinggi dalam keluarga sebagai "guru". Pemahaman posisi laki-laki sebagai pemimpin keluarga yang harus dipatuhi perintahnya, hingga saat ini masih berlaku dalam masyarakat Jawa. Akibatnya kebahagiaan keluarga, bergantung pada komitmen suami dalam memimpin keluarga. Apabila suami dapat memimpin keluarganya ke jalan yang benar, tentu akan berdampak positif bagi kebahagiaan keluarga. Sebaliknya apabila suami tidak dapat menjadi teladan yang baik bagi keluarganya, maka keluarga akan memperoleh dampak negatif yang dapat menyengsarakannya. Laki-laki yang menganggap dirinya berada di posisi yang lebih tinggi dari pasangannya, dapat berperilaku semena-mena. Akibatnya, terjadi disharmoni dalam keluarga, bahkan bisa sampai terjadi kekerasan dalam rumah tangga (KDRT).

Masyarakat Jawa mengenal ajaran kepatuhan mutlak pada suami secara turun temurun. Ajaran tersebut bersumber dari tulisan raja maupun pujangga kraton, yang disosialisasikan melalui tradisi pembacaan naskah dan upacara perkawinan. Maka terjadi internalisasi nilai di kalangan masyarakat Jawa, bahwa suami sebagai pemimpin keluarga, harus dipatuhi perintahnya dalam situasi dan kondisi apapun. Kepatuhan mutlak pada suami ini dilukiskan sebagaimana kepatuhan manusia kepada Tuhan. Apakah hal tersebut berkaitan dengan posisi raja sebagai Panatagama (pengatur kehidupan beragama) atau ada kepentingan politik kerajaan untuk menjaga stabilitas sosial dan kewibawaan raja. Hal ini menarik untuk dikaji, karena menurut ajaran Islam, kepatuhan mutlak hanyalah kepada Allah, dan Rasul-Nya (QS. al-Nisa' [4]: 59). Rasul dipilih dan ditugaskan Allah untuk menyampaikan syariat Allah kepada manusia. 
Manusia yang mematuhi Rasul, sebagai utusannya, pada hakikatnya mereka juga patuh pada Allah.

Wahyu Allah yang diturunkan kepada Rasul, menjadi pedoman bagi manusia dalam menjalani kehidupan, termasuk dalam kehidupan berumah tangga. Tanpa adanya bimbingan Allah, maka sangat mungkin manusia melakukan kesalahan atau dosa. Oleh karenanya, manusia dilarang mematuhi sesama manusia secara mutlak, tanpa mengetahui benar atau salahnya perbuatan yang diikuti. Selain itu, dalam al-Qur'an, tidak ada pembedaan derajat manusia, berdasar jenis kelamin maupun status sosial. Hal yang membedakan derajat manusia satu dengan lainnya hanyalah ketakwaannya kepada Allah. ${ }^{1}$

\section{Pemahaman tentang Kepemimpinan Kodrati}

Kajian Zamroni Ishaq terhadap kepemimpinan suami istri dalam tafsir klasik dan kontemporer menunjukkan sebagian ahli Tafsir mempunyai pendapat yang serupa bahwa laki laki merupakan pemimpin bagi perempuan, dan kepemimpinannya dalam keluarga bersifat mutlak. Meski ada perbedaan dalam membahas alasan suami sebagai pemimpin rumah tangga, tetapi Nawawi alBantany, al-Thabary, al-Raziy, dan Quraish Shihab sepakat bahwa Allah telah menjadikan suami menjadi pemimpin bagi istri, karenanya istri harus mematuhi perintah suami. Kepemimpinan dalam hal ini dimaknai sebagai kekuasaan/ kewenangan suami untuk mendidik istri. ${ }^{2}$

Allah memberikan kepemimpinan kepada laki-laki (suami), karena mereka mengemban kewajiban yang lebih banyak dibanding wanita (istri), yakni memberikan nafkah, mahar, dan memberikan perlindungan. Oleh karena itu, istri harus melaksanakan perintah suaminya. Namun, dalam kepatuhan itu terkandung azas kebenaran. Sehingga seorang perempuan harus menerima kepemimpinan suami atas dirinya, manakala suami berada dijalan yang benar.

Para ahli tafsir diatas menjelaskan keistimewaan laki-laki dibanding perempuan, terletak pada kekuatan psikis, dan fisik. Kekuatan psikis antara lain dalam kemampuan akal dan ilmu lelaki dianggap lebih tinggi; cara berpikirnya

${ }^{1}$ QS. al-Hujurat:13, "Wahai manusia kami telah menciptakan kamu dari laki laki dan perempuan, dan Kami jadikan kamu berbangsa bangsa dan bersuku suku, supaya kamu saling mengenal. Sesungguhnya yang paling mulia diantara kamu disisi Allah adalah yang paling takwa."

ZZamroni Ishaq, "Diskursus Kepemimpinan Suami Istri dalam Keluarga: Pandangan Mufassir Klasik dan Kontemporer," Jurnal Umul Qura, Vol . IV, No 2, 2014, h.. 10-31. 
yang praktis, demikian pula dalam menetapkan, mengatur, dan mengarahkan; memiliki keberanian, kekuatan, dan kemampuan mengatasi kesulitan. Kelebihan intelektual tersebut tidak terkait dengan potensi intelektualnya, melainkan pemilihan dalam penggunaan nalar dengan emosi. Laki laki cenderung menggunakan nalarnya terlebih dulu dibanding perasaannya, manakala terjadi tarik ulur dalam membuat keputusan. ${ }^{3}$ Oleh karena itu, laki laki diharapkan dapat menjalankan kewajibannya sebagai pemimpin yang bijaksana, yaitu tidak mengedepankan emosinya, yang dapat menimbulkan dampak negatif bagi keluarganya. Sedangkan kekuatan fisik terkait dengan kesempurnaan struktur tubuh yang lebih tangguh daripada perempuan, serta kesanggupan melakukan pekerjaan yang berat dengan tabah. Kondisi fisik yang kuat, menjadikan laki laki lebih kuat bekerja, sehingga mereka dapat memberi nafkah, melindungi, dan memimpin keluarganya. Keistimewaan yang dimiliki laki-laki, sebanding dengan tugas tugasnya yang berat seperti berperang. dan memenuhi kebutuhan keluarganya,yang menyebabkan ia memiliki tanggungan dan beban yang lebih besar, sehingga laki-laki memperoleh warisan lebih banyak, dari perempuan.

Sampai sekarang, pendapat kalangan ahli tafsir yang sepakat bahwa kepemimpinan harus berada di bawah kendali laki-laki, seringkali menggunakan argumentasi keistimewaan laki-laki, yang terkait dengan tugas kenabian yang hanya diberikan kepada laki-laki. ${ }^{4}$ Ada pula yang menggunakan kelebihan lain, yang merupakan hasil usaha, seperti kecerdasan, ilmu pengetahuan, maupun keterampilan. Hal hal ini dulunya dianggap hanya dapat dilakukan laki-laki, tetapi sekarang dapat dicapai pula oleh perempuan,seperti dalam hal kecerdasan. Melalui pengukuran yang terpercaya, diketahui bahwa perempuan juga bisa memiliki kecerdasan yang setara dengan laki-laki. Karenanya kelebihan laki-laki, dibanding perempuan ada yang bukan kodrati, melainkan dipengaruhi oleh konstruksi sosial budaya. Berkaitan dengan kekuatan fisik laki laki, tidak dapat dilepaskan dari pengaruh budaya patriarki yang dalam pembagian peran mengikuti teori fungsional stuktural dengan menempatkan laki laki di wilayah publik untuk melakukan tugas tugas produktif yang dipandang mempunyai tantangan fisik yang lebih berat dibanding tugas domestik. Sedang-

3Yunahar Ilyas, “Problem Kepemimpinan dalam Islam”, Tarjih Edisi ke 3, 2002, h. 69-70.

${ }^{4}$ Tim Baitul Kilmah, Ensiklopedia Pengetahuan al-Qur'an dan Hadits (Yogyakarta: Kamil Pustaka, 2013), h. 337. 
kan tugas reproduksi dan urusan di wilayah domestik diberikan kepada perempuan. Meski mendapat banyak kritikan sebagai teori yang melanggengkan keterkaitan antara peran sosial dengan jenis kelamin, tetapi teori fungsional struktural ini sulit dihilangkan. Teori ini dianggap menguntungkan bagi beberapa pihak antara lain bagi masyarakat industri yang lebih mengutamakan nilai produksi daripada nilai nilai kemanusiaan. ${ }^{5}$

Pendapat bahwa kedudukan suami sebagai pemimpin rumah tangga adalah mutlak, masih diikuti oleh sebagian besar umat Islam. Penerapan kepemimpinan kodrati dapat menjadi kebaikan, manakala suami sebagai pemimpin berjalan dijalan yang benar sesuai tuntunan agama, sehingga istri dan anak anaknya harus taat dan mengikutinya. Namun apabila suami menyimpang dari jalan yang benar, maka perintahnya tidak boleh diikuti. ${ }^{6}$

Oleh karenanya, pemahaman tentang kepemimpinan suami yang bersifat kodrati ini, sebaiknya disertai kriteria mengenai pemimpin keluarga yang sejalan dengan perintah Allah. Sebab pemahaman yang keliru terhadap ajaran agama, dapat menimbulkan sikap dominan suami terhadap istri. Saparinah Sadli mengemukakan bahwa suami yang dominan, pencemburu, dan agresif berpotensi melakukan tindak kekerasan terhadap istri. ${ }^{7}$

Kekerasan terhadap istri maupun kekerasan dalam rumah tangga menjadi salah satu sebab tingginya angka cerai gugat di Indonesia. Hasil penelitian penulis di Pengadilan Agama Semarang, menemukan beberapa penyebab cerai gugat, antara lain terjadinya kekerasan dalam bentuk fisik, psikologis, dan kekerasan ekonomi yang dilakukan suami terhadap istri. Secara terperinci, penyebab tersebut ialah persoalan ekonomi (40\%), adanya orang ketiga (24\%), perbedaan prinsip (12\%), mandul (4\%), dan krisis akhlak (20\%). Kondisi yang termasuk dalam kriteria krisis akhlak antara lain kebiasaan suami untuk minum minuman keras, berjudi, berkata tidak sopan, dan suami memiliki wanita idaman lain (WIL). ${ }^{8}$

${ }^{5}$ Nasaruddin Umar, Argumen Kesetaraan Jender: Perspektif al-Qur'an (Jakarta: Paramadina, 1999), h. 59-60.

${ }^{6} \mathrm{Abu}$ Sa'id al Khuudry meriwayatkan hadis tentang larangan mentaati perintah pemimpin yan menyuruh melakukan kemaksiyatan atau kedurhakaan kepada Tuhan.

${ }^{7}$ Saparinah Sadli, "Orientasi Seksualitas", makalah seminar yang diselenggarakan oleh PSW IAIN Sunan Kalijaga \& Ford Foundation di Yogyakarta, tanggal 27-29 April 2000, h. 19.

${ }^{8}$ Sri Suhandjati Sukri, Islam Menentang Kekerasan terhadap Istri (Yogyakarta: Gama Media, 2004), h 73-74.

JURNAL THEOLOGIA — Volume 28, Nomor 2, Desember 2017 
Realitas di masyarakat, sebagaimana tergambar pada hasil penelitian di atas, menunjukkan bahwa kepemimpinan yang melekat pada setiap laki laki, tidak selalu disertai dengan tanggungjawabnya sebagai pemimpin. Kondisi tersebut berdampak pada keutuhan keluarga. Husein Muhammad menyebutkan diantara hal yang belum banyak disadari oleh pasangan suami istri adalah pentingnya membina relasi antar suami istri. Akibat tidak adanya sikap saling menghargai dan menghormati, yang terjadi justru saling menyakiti, menghina, atau merendahkan. Sikap saling menghargai akan tercipta, manakala suami dan istri berpijak pada azas kesetaraan dalam berinteraksi dengan sesama manusia, termasuk dengan istri maupun suaminya. ${ }^{9}$

Sebagai suami, laki laki memiliki kewajiban untuk menafkahi keluarganya, berdasarkan pada perintah Allah, yakni Surat al-Baqarah: 233, dan al-Thalaq: 6 . Para Ulama sepakat bahwa pemberian nafkah merupakan suatu keharusan yang tidak boleh ditinggalkan dan terkait dengan kebutuhan pokok manusia. Kebutuhan pokok yang sebelumnya hanya mencakup kebutuhan makan, pakaian, dan tempat tinggal, saat ini mengalami perluasan, seperti kebutuhan akan pendidikan dan kesehatan. Dengan demikian, kewajiban suami dalam menafkahi istri juga bertambah.

Karena kepemimpinan suami juga terkait dengan wewenangnya untuk mendidik istrinya. ${ }^{10}$ Maka suami bertanggungjawab untuk membimbing istrinya, agar ia dapat melaksanakan tugasnya sesuai tuntunan agama, baik perannya sebagai pendamping maupun ibu. Meski sebagian perempuan bisa mandiri untuk menyelesaikan masalah yang dihadapinya, tetapi ada pula yang masih memerlukan bimbingan suami untuk menghadapi kesulitan dalam hidupnya. Selain itu, perempuan (istri) juga membutuhkan pengetahuan dan ketrampilan yang terkait dengan pendidikan, sehingga dapat mendampingi suami dalam menyiapkan anak anak sebagai generasi penerus yang tangguh.

Suami perlu membimbing dan mendorong istrinya untuk memperoleh pengetahuan yang dibutuhkan, terlebih dengan adanya tantangan pengasuhan di di era global ini. Orangtua perlu mempersiapkan kemandirian anak serta

${ }^{9}$ Husein Muhammad, Fiqh Perempuan: Refleksi Kini atas Wacana Agama dan Gender, (Yogyakarta LKiS, 2002), h. 114-115

${ }^{10}$ Nasaruddin Umar \& Amany Lubis, "Hawa sebagai Simbol Ketergantungan: Relasi Gender dalam Kitab Tafsir", dalam Ali Muhanif, Perempuan dalam Literatur Islam Klasik (Jakarta: Gramedia Pustaka Utama, 2002), h. 16. 
ketaatannya pada ajaran agama. Kepribadian yang luhur harus menjadi landasan bagi pengembangan kecerdasan anak, sehingga tidak terjadi dekadensi moral yang menimbulkan kerusakan di lingkungan keluarga maupun masyarakat.

Disamping peduli pendidikan istri, suami juga perlu menjaga kesehatan istrinya, agar istri dapat melaksanakan tugasnya dengan baik. Oleh karena itu, suami perlu memperhatian kesehatan istri, termasuk kesehatan mental dan spiritualnya. Husein Muhammad mengutip pendapat Wahbah al-Zuhaili mengemukakan bahwa suami wajib memberikan nafkah untuk pemeliharan kesehatan istrinya. Hal ini harus dilakukan agar istri sehat dan dapat melaksanakan tugas serta kewajibannya, termasuk sewaktu hamil sampai melahirkan dan selanjutnya. Ibu dan anak memerlukan gizi yang cukup agar janin dapat tumbuh dan berkembang secara normal, demikian pula setelah lahir. ${ }^{11}$

Quraish Shihab menjelaskan bahwa kepemimpinan berada pada suami, dikarenakan kelebihan yang dimiliki laki-laki lebih menunjang tugas kepemimpinan, dibanding keistimewaan yang dimiliki perempuan ${ }^{12}$ Perasaan yang sangat halus pada perempuan, juga bukanlah suatu kelemahan. Keunggulan ini justru sangat diperlukan dalam hal pengasuhan anak. Oleh karena itu, perbedaan tersebut merupakan suatu kelebihan yang saling melengkapi satu sama lain, sehingga laki-laki dan perempuan dapat saling bekerjasama, dalam menjalankan tugasnya. Melalui Surat al-Taubah: 71, Allah juga telah memberikan petunjuk, agar suami istri saling tolong menolong dalam melaksanakan kebaikan. Dengan demikian, peran dalam keluarga tidak terbatas pada siapakah pemangku kepemimpinan.

\section{Pemahaman tentang Kepemimpinan Fungsional}

Pendapat lain terkait kepemimpinan laki-laki dalam keluarga, menyebutkan bahwa tugas kepemimpinan hanya diberikan pada laki laki tertentu yang mempunyai kriteria seperti yang disebut dalam al-Qur'an, antara lain 1) Dapat membuktikan kelebihannya seperti dapat melindungi dan membimbing; 2) Mampu memberi nafkah (memenuhi kebutuhan pokok antara lain pangan, sandang, papan); 3) Mempunyai kelebihan yang telah ditetapkan oleh syariat

\footnotetext{
${ }^{11}$ Husein Muhammad, Fiqh Perempuan, h. 103.

${ }^{12}$ Quraish Shihab, Tafsir al-Mishbah: Pesan, Kesan, dan Keselarasan al-Qur'an, Jilid 2 (Jakarta: Lentera Hati, 2003),
}

JURNAL THEOLOGIA — Volume 28, Nomor 2, Desember 2017 
Islam seperti hak mendapatkan warisan dua kali lipat dari bagian perempuan dan menggunakan kelebihan itu untuk membantu perempuan. ${ }^{13}$

Keunggulan laki-laki dibanding perempuan bersifat fungsional. Artinya laki-laki yang bertugas mencari dan mampu memenuhi kebutuhan istri dan keluarganya, maka dia dapat menjadi pemimpin dalam rumah tangga. ${ }^{14}$ Lakilaki dan perempuan juga mempunyai fungsi sosial yang sama, yakni melaksanakan tugas-tugas domestik dalam rumah tangga. Oleh karena itu, bila seorang laki-laki tidak dapat memenuhi kewajiban memenuhi kebutuhan istri atau keluarganya, dan istri yang menjadi tulang punggung keluarga, maka kelebihan menjadi pemimpin keluarga tentunya menjadi milik perempuan (istri). Namun, menurut Quraish Shihab, dalam kondisi tersebut, istri belum boleh mengambil alih kepemimpinan, selama suami masih mempunyai segi keistimewaan yang dibutuhkan dalam memimpin. Meski demikian, istri diperbolehkan menggugat cerai, dan gugatannya dibenarkan. ${ }^{15}$

Pendapat tersebut didasarkan penafsiran kata "rijāl" dalam QS. al-Nisa' ayat 34, yang dimaknai sebagai laki-laki tertentu yang mempunyai kelebihan. Begitupula dengan makna kata "qawwām". Meski terdapat perbedaan tafsir, tetapi sama-sama berada dalam konteks bertanggung jawab untuk kesejahteraan jasmani maupun ruhani istri dan anak anaknya. Misalnya Ibn Katsir mengartikan "qawwām" dengan pelindung. ${ }^{16}$

Faktor kemampuan melindungi anggota keluarga, menjadi kriteria penting dalam menentukan pemegang kendali kepemimpinan. Pemahaman yang keliru atas kekuasaan, dapat menimbulkan penyalahgunaan wewenangan. Anggapan bahwa dirinya mempunyai kekuasaan untuk mengatur rumah tangganya, termasuk istri dan anak-anaknya, dapat mendorong laki-laki berpeluang melakukan kekerasan dalam rumah tangga. Seperti suami melakukan dominasi, dan membatasi akses aktivitas anggota keluarga. Kondisi ini sering dijumpai pada masyarakat di berbagai negara yang menganut budaya patriarki dan memberikan posisi laki laki lebih tinggi dari perempuan. ${ }^{17}$ Umumnya kebudayaan ini

${ }^{13}$ Nasaruddin Umar \& Amany Lubis, “Hawa sebagai Simbol Ketergantungan...”, h. 17.

${ }^{14}$ Asghar Ali Engineer, Hak-hak Perempuan dalam Islam, terj. Farid Wajdi \& Cici Farkha Asgaf, (Yogyakarta: LP3ES ,1994), h. 62.

15Zamroni Ishaq, “Diskursus Kepemimpinan Suami Istri dalam Keluarga...”, h.10-31.

16Ibid., h. 15.

${ }^{17}$ B. Rudi Harnoko, "Dibalik Tindak Kekerasan terhadap Perempuan”, Muwazah, Vol.2, No.1, 2010, h. 181-188 
menurun, karena adanya proses crime imitation model (peniruan model kejahatan). Anak yang tumbuh di keluarga tersebut, akan menganggap tindakan kekerasan yang dilakukan ayah kepada ibu merupakan hal yang wajar, dan cenderung meniru pola yang sama ketika ia memiliki pasangan. ${ }^{18}$

Kasus kekerasan terhadap perempuan merupakan permasalahan universal, sehingga mendorong Perserikatan Bangsa Bangsa (PBB) untuk mengeluarkan deklarasi PBB tahun 1993 tentang penghapusan segala bentuk kekerasan terhadap perempuan. Perempuan memiliki kerentanan terhadap tindak kekerasan, baik yang di sektor domestik, publik atau masyarakat. Namun, sangat disayangkan, saat ini belum ada sistem yang dapat memberikan perlindungan seutuhnya bagi perempuan. Bahkan Undang-Undang No.20 Tahun 2003 dinilai belum efektif untuk memberikan perlindungan bagi korban KDRT. ${ }^{19}$ Sebagai gambaran peningkatan angka kekerasan terhadap perempuan di Indonesia, dapat dilihat pada Grafik 1.

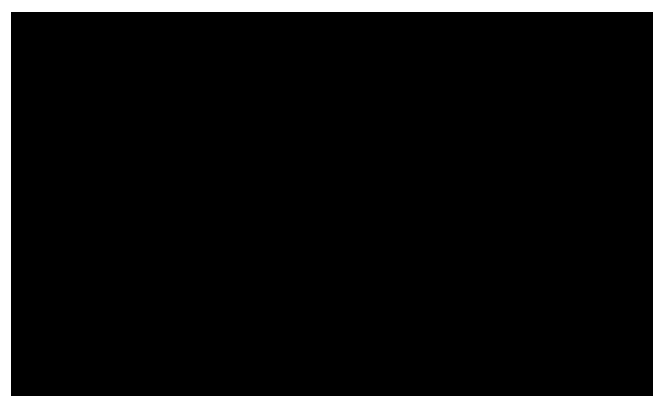

Gambar 1

Grafik Angka Kekerasan terhadap Perempuan di Indonesia ${ }^{20}$

Meski pemerintah dan masyarakat sudah melakukan usaha preventif, tetapi kekerasan terhadap perempuan dan anak tidak mengalami penurunan, bahkan cenderung terjadi peningkatan dari tahun ketahun. Berdasarkan data yang dikumpulkan dari 359 Pengadilan Agama dan 233 lembaga mitra layanan

${ }^{18}$ Kurnia Muhajarah, "Kekerasan terhadap Perempuan dalam Rumah Tangga: Perspektif Sosio-Budaya, Hukum, dan Agama”, Sawwa: Jurnal Studi Gender, Vol.11, No. 2, 2016, h.127-146, , http://dx.doi.org/10.21580/sa.v11i2.1452, diakses pada tanggal 3 April 2017.

${ }^{19}$ Zulfatun Ni'mah, "Efektivitas Penegakan Hukum Penghapusan Kekerasan dalam Rumah Tangga", Mimbar Hukum Vol.24 No.1, 2012, h. 55-68

${ }^{20}$ Catatan Tahunan Komisi Nasional Perempuan, diakses dari https://www. komnasperempuan.go.id/ pada tanggal 3 April 2017.

JURNAL THEOLOGIA — Volume 28, Nomor 2, Desember 2017 
yang berada di 34 propinsi di Indonesia, Komnas Perempuan mencatat adanya hampir sebanyak 260.000 kasus kekerasan terhadap perempuan yang terjadi di Indonesia pada tahun $2016 .^{21}$

Dilihat dari perbandingan pada tahun 2015 dan 2016, terlihat adanya penurunan angka terjadinya kekerasan dalam rumah tangga. Namun, angka tersebut masih tergolong cukup tinggi. Selain itu, angka tersebut belum dapat menggambarkan jumlah kasus yang terjadi di lapangan secara tepat. Hal tersebut dikarenakan tidak semua korban KDRT bersedia membuka rahasia rumah tangga mereka, apalagi untuk dipublikasikan. Penelitian pada waktu yang sama, dapat memiliki hasil yang berbeda, karena faktor perbedaan responden maupun lokus penelitian.

Gambaran tersebut di atas menunjukkan adanya kebutuhan untuk melakukan reinterpretasi berperspektif jender, terhadap ayat kepemimpinan laki laki dalam rumah tangga. Dengan mempertimbangkan realitas yang terjadi di masyarakat, maka hasil rekonstruksi kepemimpinan dalam keluarga diharapkan dapat membantu suami dalam melaksanakan tugas kepemimpinannya. Suami mengetahui dengan jelas perlindungan yang harus dilakukan terhadap istri dan anak anaknya, di era modern ini. Dengan demikian, diharapkan terjadi penurunan angka kasus kekerasan terhadap perempuan dan anak.

\section{Kepemimpinan Perempuan dalam Keluarga}

Pendapat tentang kepemimpinan perempuan dalam keluarga, dikemukakan Forum Kajian Kitab Kuning (FK3), dengan merujuk pada penafsiran Muhammad Abduh dalam Tafsir Al Manar tentang kelebihan laki-laki atas perempuan, sebagaimana tersebut dalam QS. al-Baqarah [2]: 228. Manakala lakilaki dapat memenuhi kewajibannya untuk melindungi dan memberikan kesejahteraan bagi keluarganya, maka ia dinilai mempunyai kelebihan dibanding perempuan. Sebaliknya, jika istri dapat mencukupi kebutuhan keluarga dan mampu melindungi keluarganya, maka istri yang berhak mempunyai kelebihan. ${ }^{22}$ Oleh karena itu, kendali kepemimpinan dalam keluarga dipegang oleh orang yang dapat mencukupi kebutuhan, dan melindungi keluarga. Pengakuan

\footnotetext{
${ }^{21} \mathrm{https} / /$ www.komnasperempuan.go.id diakses 29 November 2017.

${ }^{22}$ Forum Kajian Kitab Kuning (FK3), Wajah Baru Relasi Suami Istri: Telaah Kitab 'Uqud al Lujjayn (Yogyakarta: LKiS, 2001), h. 12.
} 
kepemimpinan akan membawa konsekuensi dipatuhinya perintah sang pemimpin.

Apabila perempuan yang mempunyai kelebihan, maka ia juga bisa memimpin keluarganya. Quraish Shihab membuka kemungkinan kepemimpinan perempuan dalam masyarakat dengan merujuk pada tuntunan al-Qur'an. ${ }^{23}$ Hadis yang diriwayatkan Imam Bukhari dan Muslim menjelaskan, bahwa setiap orang pada hakikatnya adalah pemimpin. Suami adalah pemimpin bagi keluarganya, sementara istri juga pemimpin dalam rumah tangga suaminya. Masing masing akan diminta pertanggungjawabannya. Sejarah dalam al-Qur'an juga membuktikan bahwa perempuan dapat menjadi pemimpin dalam pemerintahan, dan berhasil memakmurkan negaranya, seperti Ratu Balqis dari negara Saba'.

Kepemimpinan laki laki maupun yang dijalankan oleh perempuan, harus mengutamakan adanya kemaslahatan dan menghindarkan diri dari berbuat kedzaliman maupun hal hal yang mendatangkan kemadharatan. Tugas pemimpin antara lain mengarahkan pada tujuan kehidupan berkeluarga, yakni kebahagiaan surgawi ketika di dunia hingga akherat kelak. Manakala suami sudah berjalan menurut ketentuan agama, maka istri dan anak anaknya harus mengikuti langkah pemimpinnya dan mematuhi perintahnya. Sebaliknya, apabila suami menyimpang dari tuntunan Allah, maka istri berkewajiban untuk mengingatkan dan mengajak kepada jalan yang benar. Apabila suami menolak untuk kembali kejalan yang benar, maka kepemimpinan dalam keluarga dapat diambilalih oleh istri, dengan tujuan agar keluarga terhindar dari dampak buruk perilaku suami. Istri juga mempunyai kemampuan untuk mengambil alih kepemimpinan dalam keluarganya, ketika dihadapkan dalam situasi darurat, seperti suami sakit atau di PHK atau bahkan meninggal dunia.

\section{B. Implementasi Kepemimpinan Laki laki dalam Masyarakat Jawa}

\section{Raja sebagai Sayidin Panatagama Khalifatullah}

Raja di Jawa,terutama di kerajaan Mataram mempunyai gelar Ngabdurrahman Sayidin Panatagama Khalifatullah. Gelar ini berkaitan dengan kepemim-

\footnotetext{
${ }^{23}$ Nasaruddin Umar, Argumen Kesetaraan Jender..., h. 151. Lihat QS. al-Taubah [9]: 71 yang mengemukakan tentang potensi laki laki dan perempuan untuk saling tolong menolong dalam kebaikan, amar ma'ruf nahi munkar, mengerjakan salat, membayar zakat, serta ketaatan pada Allah dan Rasul-Nya.
}

JURNAL THEOLOGIA — Volume 28, Nomor 2, Desember 2017 
pinan dalam kehidupan beragama rakyatnya. Sejak didirikannya Kesultanan Mataram di Yogyakarta pada tahun 1755 M, Raja telah menetapkan bahwa agama resmi kerajaan adalah Islam. Raja merupakan khalifatullah, yaitu wakil Allah dibumi yang bertugas memakmurkan dunia berdasarkan pada tuntunan Islam. $^{24}$

Raja juga sebagai Panatagama atau pengatur kehidupan beragama, sehingga bertanggungjawab untuk menyebarluaskan ajaran Islam di kalangan rakyatnya. Gelar Sayidin Panatagama Khalifatullah ini memperlihatkan karakteristik kepemimpinan Jawa yang senantiasa mengkaitkan dengan kekuatan gaib diluar diri, yang diyakini akan membantu keberhasilan dalam tugas kepemimpinannya.

Anderson menyebutkan dua karakteristik kekuasaan Jawa. Pertama, bercorak sentralistik yang berdampak pada terbentuknya kekuasaan yang dominan, dan pengambilan keputusan berada ditangan pimpinan tertinggi. Karakteristik kedua, kekuasaan diperoleh dari alam ilahiah, bukan dari rakyat atau pihak lain. Penguasa tidak dituntut untuk mempertanggungjawabkan kebijakan dan hasil kerjanya kepada rakyat atau pihak lainnya. ${ }^{25}$

Kekuasaan sentralistik ini yang mendukung dilaksanakannya doktrin Agung Binatara, yakni "wenang wisesa ing sanagari" (arti: berwenang mengatur atau memerintah seluruh negeri), yang bermakna raja mempunyai kekuasaan mutlak. Kekuasaan raja dapat dilihat dari beberapa hal antara lain: a) Luas wilayah kerajaannya; b) Kesetiaan pegawainya untuk melaksanakan tugas, baik dari pegawai tinggi yang dipusat pemerintahan, sampai pegawai rendah yang berada didaerah; c) Besarnya kekuatan pasukan dan perlengkapannya; d) Banyaknya gelar yang dimiliki dan kemasyhurannya; e) Kekuasaan dalam semua urusan ada ditangannya,dan tidak ada yang menandinginya. ${ }^{26}$

Konsep Raja Agung Binathara tersebut berasal dari Hindu yang memandang raja adalah keturunan atau titisan Dewa. Setelah masa Islam, konsep ini berubah menjadi Raja adalah khalifatullah, yakni wakil Allah di bumi. Meskipun

${ }^{24}$ Soelarto B, Garebeg di Kesultanan Yogyakarta (Yogyakarta: Penerbit Kanisius, 1993), h. 36.

${ }^{25}$ Benedict Anderson, "Karakteristik Kekuasaan Jawa" sebagaimana dikutip oleh Suwardi Endrasworo, Falsafah Kepemimpinan Jawa, (Jakarta: Penerbit NARASI, 2003), h. 12,13.

${ }^{26}$ Moedjanto, G, Konsep Kekuasaan Jawa: Penerapannya oleh Raja-raja Mataram (Yogyakarta: Kanisius, 1994), h. 79-80. 
kekuasaan raja masih besar, tetapi ada batasnya sebagai kekuasaan manusia yang mempunyai kelemahan. Oleh karena itu, terdapat beberapa kewajiban yang harus dilaksanakan Raja, yang dikenal dalam kalangan masyarakat keraton, yakni"ratu gung binathara (raja besar), bau dhenda (yang mempunyai kekuatan), nyakrawati(penguasa dunia), berbudi (kebaikannya mengalir terus menerus), bawa leksana (memegang teguh kata katanya), ambek adl paramarta (bersifat adil dan murah hati). Manakala raja dapat melaksanakan kebaikan yang terus menerus, bersifat adil dan murah hati, maka raja dapat menempati posisi ratu binathara utama. Namun, apabila raja tidak memperhatikan kebaikan yang harus dilakukan, maka raja termasuk dalam tingkatan madya (tengah). Sedangkan raja yang dalam menjalankan pemerintahannya menyimpang atau menyalahi tugas tugas tersebut, maka termasuk dalam tingkatan nistha (rendah atau hina). ${ }^{27}$ Oleh karena itu, raja harus berpegang pada hukum agar dapat berlaku adil. ${ }^{28}$

Adanya aturan yang membatasi wewenang Raja, merupakan upaya preventif dari kerajaan untuk menjaga agar citra raja tetap baik. Namun, sebagai manusia, raja tentu mempunyai kekurangan, termasuk dalam memimpin keluarganya.

Terkait dengan tugasnya sebagai pengatur kehidupan beragama rakyatnya, maka raja melakukan beberapa hal, seperti membangun tempat ibadah berupa masjid dekat dengan Kraton dan Alun-alun. Raja Mataram maupun keturunannya yang menjadi Raja di Surakarta dan Yogyakarta, mengikuti jejak pendahulunya untuk membangun masjid. Salah satunya, Sultan Agung yang dikenal sebagai raja yang banyak melakukan upaya untuk menyebarkan Islam di wilayah kekuasannya. Raja dikenal rajin shalat di Masjid, dan para pejabat kerajaan diharuskan ikut shalat di masjid. Demikian pula, pada waktu diadakan upacara Maulud Nabi di masjid yang disertai bunyi gamelan sekaten, Sultan juga pergi ke masjid untuk menghadiri acara tersebut. Upaya mengatur kehidupan agama bagi rakyat Mataram, juga ditempuh melalui penyusunan tahun Jawa yang merupakan perpaduan kalender hijriah dengan tahun saka. Melalui karya sastra yang ditulis para pujangga dan raja, maka disampaikan pula sosialisasi 1989), h. 4-5.

27Darsiti Soeratman, Kehidupan Dunia Kraton Surakarta 1830-1939 (Yogyakarta: Tamansiswa,

${ }^{28}$ K.S. Pakubuwono IV, Serat Wulangreh (Semarang: Dahara Prize, 1989), h. 16. 
tentang norma norma agama maupun budaya Jawa yang terkait dengan kehidupan keluarga maupun sosial.

\section{Kepemimpinan Raja dalam Kehidupan Keluarga}

Dalam kehidupan pribadinya, Raja dan keluarganya menikah secara Islam dan putra putra raja yang akan sunat juga harus membaca Syahadat di depan penghulu Kraton 29

Raja raja Mataram maupun keturunannya termasuk raja di keraton Surakarta maupun Yogyakarta menganut perkawinan poligami. Istri utama Raja adalah Permaisuri dan selainnya disebut selir atau garwa ampeyan atau garwa paminggir sering pula disebut priyantun dalem. Meskipun raja beragama Islam, tetapi raja mempunyai banyak selir, sehingga istrinya lebih dari empat. Pada umumnya, selir adalah penari kraton yang berasal dari anak abdi dalem (pelayan Raja). Gadis anak abdi dalem yang berusia sekitar dua belas tahun, dibawa masuk ke keraton dan berhubungan dengan raja. Mereka dinikahi oleh raja, dan menjadi selir, ketika ia mengandung dari hasil hubungan tersebut. Namun, ada pula yang tidak dinikahi meski sudah mengandung. Apabila raja tidak berkenan menjadikannya sebagai selir, maka gadis tersebut akan diberikan kepada abdi dalem. Padahal dalam Islam, laki laki yang berpoligami dibatasi hingga empat istri, oleh karena itu, status selir tidak diakui. ${ }^{30}$

Dari kasus pernikahan poligami raja, tampak bahwa kepemimpinan laki laki dalam keluarga Raja menganut kepemimpinan Kodrati, yakni setiap laki laki adalah pemimpin bagi istrinya. Meskipun raja telah menyimpang dari ajaran Islam (sebagai contoh dalam kasus selir yang tidak dinikahi), tetapi raja tetap sebagai pemimpin keluarga yang dipatuhi oleh istrinya. Hal ini menunjukkan tidak adanya kriteria yang jelas tentang tanggung jawab terhadap istri, dalam model kepemimpinan kodrati.

Secara formal, Raja mengikuti aturan Islam dalam pernikahan poligami dengan empat istri. Namun realitasnya menyimpang dari tuntunan Islam, yaitu dengan banyaknya selir dan prosedur pernikahan juga tidak mengikuti aturan Islam. Dari naskah naskah Keraton yang ditulis Raja maupun pujangga, tampak

${ }^{29}$ Soelarto, B, Garebeg di Kesultanan, h. 36-37.

30Darsiti Soeratman, Kehidupan Dunia Kraton Surakarta..., h. 50-58. 
bahwa raja mengikuti penafsiran kepemimpinan kodrati, yang memposisikan laki laki sebagai pemimpin yang harus dipatuhi secara mutlak. Penafsiran ini tidak hanya dikuti oleh raja Mataram, tetapi juga kerajaan penerusnya seperti Surakarta, dan Yogyakarta. Tetapi di Kraton Yogyakarta sekarang, Sultan Hamengku Buwana $\mathrm{X}$ hanya mempunyai permaisuri, dan tidak ada selir. Hal ini merupakan perbaikan sistem perkawinan raja yang semula poligami menjadi monogami.

Mengenai raja yang menganut perkawinan poligami, tampaknya dalam waktu yang cukup lama sudah menjadi tradisi. Dampak dari poligami bagi para putri yang menjadi istri raja, kiranya hampir sama yakni menimbulkan konflik antar mereka. Karena itu, muncul tulisan para pujangga maupun raja yang mencela istri atau perempuan yang mencela atau berbuat tidak baik terhadap madunya.

Pujangga Kraton Surakarta Yasadipura II dalam Serat Wicarakeras mengemukakan perbuatan yang harus dilakukan seorang perempuan terhadap suaminya, antara lain adalah takut kepada suami, tidak boleh membantah atau menolak perintahnya, serta tidak boleh menghalangi kemauan suami (Wicarakeras, pupuh 5 bait 21). Melalui serat serat piwulang, raja atau pujangga menanamkan nilai toleransi antar istri raja. Dalam Serat Wulangreh Putri karya Sunan Pakubuwana IV, dikemukakan bahwa yang termasuk budi wanita yang baik adalah tidak menganggap istriistri suami selain dirinya sebagai saingan. Sebaiknya sikap terhadap madu adalah rendah hati dan menyayanginya. ${ }^{31}$

Dalam Serat Candra Rini karya Ranggawarsita, seorang pujangga Kraton Surakarta, dituliskan bahwa kepatuhan istri pada suami setara dengan kepatuhan kepada Tuhan atau Dewa. Secara eksplisit disebutkan "Sungku sungkeme ngawulo ing kakung, pangrenkuhe Bathara, Di ngudi kawidadanipun, jrih terus ing lair batin, cunduk cumadong ing karso ${ }^{32}$

Pujangga keraton sebagai pegawai kerajaan, kiranya tidak akan menulis sesuatu yang berbeda atau bertentangan dengan yang diperintahkan oleh Raja. Bahkan sebagian besar karya pujangga merupakan pesanan atau dibuat atas

\footnotetext{
${ }^{31}$ K.S. Pakubuwono IV, Serat Wulangreh, pupuh 2, bait 13-16.

${ }^{32}$ Serat Candrarini, Megatruh, bait 42.43. Arti dari kalimat tersebut diatas adalah: "Adapun bakti dan mengabdinya (istri) kepada suami seperti baktinya kepada Dewa, mencari kebahagiaan lahir maupun batin, tunduk patuh serta siap melaksanakan apa yang dikehendaki (suami)".
} 
perintah Raja. Misalnya, Serat Centhini yang ditulis atas perintah Pangeran Adipati Anom (setelah menjadi Raja bergelar Sunan Pakubuwana V) juga memuat perintah kepada perempuan agar taat pada suami, tidak membantah dan bersikap pasrah serta mengikuti kemauan suami. ${ }^{33}$ Dalam pupuh selanjutnya dikemukakan sifat "takut" yang perlu dimiliki perempuan terhadap suaminya adalah menyerah, pasrah dan tidak suka mencela, membantah atau menolak pembicaraan. ${ }^{34}$

Beberapa tulisan dalam karya sastra diatas,menunjukkan adanya dominasi raja terhadap para istrinya. Kepasrahan permaisuri terhadap kemauan raja untuk menambah istri atau selir, merupakan bukti lemahnya kedudukan istri di hadapan Raja. Sebagian besar selir raja berasal dari penari kraton, yang sejak usia 12 tahun sudah tinggal di keraton. Tercatat pada masa Sunan Pakubuwana $\mathrm{X}$, terdapat sekitar seratus penari yang tinggal di keraton, dan sebagian besar dari mereka berharap untuk dijadikan sebagai selir raja. Banyaknya jumlah istri yang dimiliki Raja, berdampak pada keharmonisan hubungan di antara para istri Raja, yakni seringkali terjadi konflik antara permaisuri dan selir. Mereka saling bersaing untuk memperebutkan perhatian raja, karena mempunyai harapan agar anak anak yang mereka lahirkan dapat ditunjuk menjadi pengganti raja atau putra Mahkota. ${ }^{35}$ Banyaknya masalah yang tidak terselesaikan, yang timbul di antara para istri menyebabkan kehidupan di Keputren diwarnai oleh konflik internal sesama istri raja.

Konflik yang memanas diantara istri raja, memunculkan urgensi untuk mengatur interaksi antar putri raja maupun antar selir dengan penghuni keputren lainnya. Karya sastra sudah lama menjadi media komunikasi raja dalam menyampaikan perintah maupun larangannya. Oleh karena itu, ditulislah buku buku atau serat piwulang untuk anak anak putri (Serat Wulang Estri) dan buku untuk anak laki laki (Serat Wulangsunu). Melalui strategi budaya tulis semacam ini, maka banyak lapisan masyarakat yang dapat mengetahui apa yang diharapkan rajanya. Karya tulis mempunyai masa baca yang lebih panjang dibandingkan dengan komunikasi lisan. Sosialisasi dan internalisasi nilai lebih mudah dilakukan, karena tulisan dapat dibaca oleh orang banyak. Oleh karena

\footnotetext{
${ }^{33}$ Sunan Pakubuwana V, Serat Centhini, 360: 32.

${ }^{34}$ Sunan Pakubuwana V, Serat Centhini, 380: 82.

35Darsiti Soeratman, Kehidupan Dunia Kraton.., h. 87.
} 
itu, raja menggunakan media tulisan untuk menyebarkan hal-hal yang penting. Misalnya, sosialisasi mengenai konsep manunggaling kawula-Gusti. Hal ini perlu disampaikan agar rakyat mengetahui kedudukan raja sebagai khalifatullah, yang mempunyai kekuatan di luar dirinya. Prinsip ini merupakan ajaran kraton yang sinkretis yang telah dianut oleh masyarakat Jawa sebelum Islam. Konsep ini digunakan untuk menyambut ajaran Islam yang mulai dipeluk oleh raja. Karena dalam realitasnya, lingkungan kraton dan masyarakat Jawa masih sulit meninggalkan kepercayaan lamanya, sehingga ditempuh strategi budaya dengan memadukan ajaran Islam dan kepercayaan Jawa.

Tersedianya karya tulis di kalangan masyarakat Jawa, merupakan media penyampai gagasan yang strategis dan sudah lama dikenal oleh masyarakat. Kiranya penafsiran tentang kepemimpinan dalam keluarga, bisa disampaikan pula melalui media yang bisa mendekatkan dengan pembaca yang dituju dalam penulisan.

\section{Perlunya Reinterpretasi tentang Kepemimpinan dalam Keluarga.}

Penafsiran al-Qur'an menurut Quraish Shihab perlu dilakukan sepanjang waktu agar pemeluk Islam dapat memahami dengan mudah dan tepat sesuai dengan zamannya. Karena penafsiran merupakan hasil pemikiran yang dipengaruhi oleh banyak faktor, seperti tingkat kecerdasan penafsirnya, disiplin ilmu yang dikembangkan, setting sosial budaya masyarakatnya, pengalaman yang dimilikinya, maka dimungkinkan adanya perbedaan penafsiran tentang suatu ayat. ${ }^{36}$

Asghar mengambil contoh, penafsiran keunggulan lelaki atas perempuan seperti yang dijelaskan dalam Al-Qur'an, berkaitan dengan konteks sosial di masyarakat, saat ayat Al-Qur'an diturunkan. Laki-laki menganggap dirinya lebih unggul, karena kekuasaan dan kemampuannya dalam mencari nafkah, sementara kesadaran sosial perempuan pada masa itu sangat rendah. Mereka hanya melakukan pekerjaan domestik yang dianggap sebagai kewajiban perempuan. Sementara pada saat ini, keistimewaan laki-laki yang sebelumnya menjadi dasar atas kepemimpinannya dalam rumah tangga, juga dapat dicapai

\footnotetext{
${ }^{36}$ Quraish Shihab, Membumikan al-Qur'an.., h. 77.
} 
oleh perempuan. Misalnya, perihal menjadi ulama, atau menjadi pemimpin, perempuan saat ini telah membuktikan dirinya memiliki kemampuan yang sama untuk memegang kepemimpinan tersebut. 37

Terkait dengan pemahaman tentang kepemimpinan laki laki dalam keluarga, kiranya dapat dilakukan reinterpretasi yang menyangkut konteks sosial budayanya. Sampai sekarang, penafsiran kontekstual masih sedikit yang mengkaitkan dengan kebutuhan masyarakat lokal yang mempunyai tradisi yang telah berakar sampai sekarang seperti masyarakat Jawa. Penyampaian ide dikalangan masyarakat Jawa melalui simbol simbol, merupakan ciri khusus interaksi dalam masyarakat Jawa. Dengan mengetahui latar belakang budaya masyarakat disuatu daerah, maka reinterpretasi akan dapat dilakukan secara integral. Misalnya, tentang kepatuhan istri terhadap suami dalam masyarakat Jawa menggunakan simbol yang berupa perilaku maupun saloka (kata kata yang mengandung nasihat). Gambaran tentang penghormatan dan kepatuhan pada suami yang dilakukan pada upacara pernikahan dengan adat Jawa, merupakan salah satu media sosialisasi tentang penghormatan kepada suami menurut tradisi Jawa. Pengantin perempuan melakukan sikap jongkok di hadapan suami sambil mencuci kaki suaminya yang kotor setelah menginjak telor. Adegan ini merupakan simbol kerjasama antara suami istri dalam rangka mendapatkan keturunan yang dilambangkan dengan pemecahan telor dengan diinjak. Namun, banyak tafsiran yang cenderung pada penggambaran tentang superioritas laki laki dan inferioritas istri. Hal ini memicu timbulnya sikap apriori sebagian aktivis perempuan terhadap budaya Jawa yang dinilai feodal dan bertentangan dengan ajaran Islam yang mengajarkan kesetaraan.

Simbol simbol itu sering ditangkap atau dimaknai berbeda oleh orang yang tidak memahami corak budaya Jawa. Penafsiran yang salah ini, merupakan contoh sebagian kecil dari problem yang dapat menghalangi integrasi antara budaya lokal dengan pemahaman agama. Padahal untuk membumikan alQur'an, diperlukan media yang memudahkan ajaran tersebut dipahami oleh pemeluk Islam yang tinggal di wilayah kebudayaan tersebut. Cara penghormatan seorang istri kepada suaminya, tidak dapat dilepaskan dari adat kebiasaan yang tumbuh dan berkembang di daerah tersebut. Selama media itu tidak bertentangan dengan prinsip Islam, kiranya dapat digunakan untuk me-

\footnotetext{
${ }^{37}$ Asghar Ali Engineer, Hak-hak Perempuan, h.. 62.
} 
nyampaikan ajaran Islam,termasuk dalam penghormatan kepada suami sebagai kepala keluarga.

Peluang untuk menafsirkan ulang suatu ayat masih terbuka, tetapi harus disertai tanggung jawab moral dan keilmuannya. Pembatasan dalam menafsirkan al-Qur'an menurut Quraish Shihab antara lain: 1) Dilakukan oleh orang yang mempunyai pengetahuan tentang bahasa Arab dengan bidang bidangnya, 2) Menguasai tentang ilmu ilmu al-Qur'an, sejarah turunnya al-Qur'an, hadis hadis Nabi dan Ushul Fiqh, 3) Memiliki pengetahuan mengenai prinsip prinsip pokok keagamaan, 4) Mempunyai pengetahuan tentang disiplin ilmu yang menjadi bahasan ayat ${ }^{38}$ Kriteria ini dibutuhkan, karena tafsir menyangkut isi kitab suci, sehingga hanya orang orang yang memenuhi syarat seperti tersebut diatas yang boleh menafsirkan ayat al-Qur'an.

Quraish Shihab menyarankan bahwa reinterpretasi kepemimpinan dalam keluarga, sebaiknya berfokus pada kelebihan, dan kekurangan di antara suami istri. Lelaki (suami) mendapatkan darajah (kepemimpinan di atas istri) dengan menekankan pada musyawarah, kelapangan dada suami meringankan sebagian kewajiban istri, memperlakukan istri secara terpuji. Dengan demikian, kepemimpinan yang dilakukan dapat menjadi perajut kebersamaan, guna membentuk keluarga yang sakinah, mawaddah, dan rahmah. ${ }^{39}$

\section{Kesimpulan}

Kebudayaan Jawa menganut kepimpinan kodrati, yaitu istri diajarkan untuk menuruti perintah suami, dan tidak boleh melawan. Ajaran ini telah dilaksanakan secara turun temurun dan menjadi bagian dari budaya patriarki. Laki-laki mempunyai posisi yang lebih tinggi dari perempuan. Keberadaan ayat ayat suci yang menjelaskan kelebihan laki-laki digunakan untuk memperteguh dominasi laki laki dalam rumah tangga sebagaimana diajarkan dalam budaya Jawa. Pemahaman yang tidak tepat, berdampak negatif bagi keharmonisan keluarga. Data di lapangan menunjukkan tingginya angka perceraian yang disebabkan sikap dominan suami, sehingga istri mengalami kekerasan fisik, psikis maupun ekonomi. Realitas ini menunjukan bahwa praktik kepemimpinan

38 Ibid., h. 79.

${ }^{39}$ Zamroni Ishaq, Diskursus Kepemimpinan..., h.10-31. 
kodrati perlu dikaji ulang dan disempurnakan dengan penafsiran kontekstual yang berperspektif jender. Sebaiknya interpretasi juga mempertimbangkan lokal wisdom yang dapat digunakan sebagai media penyampaian penafsiran kontekstual. Dengan demikian, interpretasi dapat menjadi jalan keluar bagi para pemeluk Islam yang masih berpegang pada tradisi, tetapi ingin pula mematuhi ajaran agamanya.[]

\section{DAFTAR PUSTAKA}

Endraswara, Suwardi, Falsafah Kepemimpinan Jawa, Yogyakarta: NARASI, 2013

Engineer, Asghar Ali, Hak-hak Perempuan dalam Islam, terjemahan Farid Wajidi danCici Farkha Assegaf, Yogyakarta: LP3ES, 1994

Forum Kajian Kitab Kuning, Wajah Baru Relasi Suami Istri: Telaah Kitab 'Uqud al Lujjayn, Yogyakarta:LKiS, 2001.

Harnoko, Rudi B, "Di balik Tindak Kekerasan terhadap Perempuan", Muwazah Vol.2 No.1, 2010.

Ilyas, Yunahar, “Problem Kepemimpinan dalam Islam’, Tarjih Edisi ke 3, 2002.

Ishaq, Zamroni, "Diskursus Kepemimpinan Suami Istri dalam Keluarga: Pandangan Mufassir Klasik dan Kontemporer", Jurnal Umul Qura, Vol IV No 2, 2014

Moedjanto, G, Konsep Kekuasaan Jawa: Penerapannya oleh Raja-raja Mataram, Yogyakarta: Kanisius, 1994

Muhajarah, Kurnia, "Kekerasan terhadap Perempuan dalam Rumah Tangga: Perspektif Sosio-Budaya, Hukum, dan Agama", Sawwa: Jurnal Studi Gender, Vol. 11, No. 2, 2016, h.127-146, http://dx.doi.org/10.21580/ sa.v11i2.1452

Muhammad, Husein, Fiqh Perempuan, Refleksi Kiai atas Wacana Afama dan Gender, Yogyakarta: LKiS, 2002

Ni'mah, Zulfatun, Efektivitas Penegakan Hukum Penghapusan Kekerasan dalam Rumah Tangga, Mimbar Hukum, Vol. 24 No.1, 2012. 
Pakubuwono IV, K.S, Serat Wulangreh,Semarang: Dahara Prize, 1989.

al-Razi, Fakhruddin, al-Tafsir al-Kabir, juz X, Teheran: Dar al-Kutub

Sadli, Saparinah, Orientasi Seksualitas,dalam makalah Seminar yang diselenggarakan oleh PSW IAIN Sunan Kalijaga \& Ford Foundation, Yogyakarta, tanggal 27-29 APRIL 2000.

Shihab, Quraish, Membumikan Al-Qur'an: Fungsi dan Peran Wahyu dalam Kehidupan Masyarakat, Bandung: Mizan, 1994

Tafsir al-Mishbah: Pesan, Kesan, dan Keselarasan al-Qur'an Jilid 2, Jakarta: Lentera Hati, 2003.

Soelarto, B, Garebeg di Kesultanan Yogyakarta, Yogyakarta: Kanisius, 1993.

Soeratman, Darsiti, Kehidupan Dunia Kraton Surakarta 1830 - 1939, Yogyakarta: Penerbit Tamansiswa, 1989.

Sukri, Sri Suhandjati, Islam Menentang Kekerasan terhadap Istri, Yogyakarta:Gama Media, 2004.

Tim Baitul Kilmah, Ensiklopedia Pengetahuan al-Qur'an dan Hadits, Yogyakarta: Kamil Pustaka, 2013.

Umar, Nasaruddin; Lubis, Amany, "Hawa sebagai Simbol Ketergantungan: Perempuan dalam Kitab Tafsir", dalam Ali Munhanif (Ed.), Mutiara Terpendam, Perempuan dalam Literatur Islam Klasik, Jakarta: PT. Gramedia Pustaka Utama, 2002

https://www.komnasperempuan.go.id/ 
